\title{
Soviet academician makes rare appearance at US Congress
}

\section{Washington}

In one of the extremely rare appearances of Soviet citizens before the US Congress, Academician Evgeny Velikhov, vicepresident of the Soviet Academy of Sciences, spoke out on Chernobyl and the Strategic Defense Initiative (SDI). He was giving evidence to the Senate Labor and Human Resources Committee, chaired by Senator Edward Kennedy (Democrat, Massachusetts).

Velikhov fielded questions about the causes and consequences of the accident last April at the Number 4 reactor at Chernobyl, where his involvement began just days after the event. Much of his testimony reiterated well-known facts about Chernobyl. He blamed the accident on "multiple errors and deviation from procedure" that allowed the reactor core to overheat. The six operator errors leading to the accident were "unthinkable", according to Velikhov, and yet they happened. He specifically blamed the technicians involved for not discussing their plans with plant physicists and safety personnel.

Decontaminating the reactor site has been difficult. Although, Velikhov said, physical damage to the reactor building itself was surprisingly small, the radioactive debris deposited both near the reactor and in an area extending $30 \mathrm{~km}$ from the reactor was the real problem. Remotely controlled equipment was used to remove radioactive debris, but failures were common. Velikhov suggested that the United States and Soviet Union should collaborate on the technology of machines to operate in radioactive environments.

Thirty-one people died from injuries acquired at Chernobyl, although there was only one death from the fire and explosions on the day of the accident. Velikhov said that most of the other 237 who were hospitalized have now returned to work. In testimony later in the hearing, Robert Gale, the physician at the University of California, Los Angeles, who performed bone marrow transplants on victims of the accident, said that there may be as many as 150,000 additional cancers over the next 50 years attributable to radiation from Chernobyl, but he added that this number must be compared with the expectation that total cancers worldwide in the same period would number 1,000 million. Gale also said the Soviet Union is establishing a register of all 135,000 people evacuated from the Chernobyl area to study health effects of the accident.

The scope of the clean-up is staggering. Three hundred thousand cubic metres of concrete - enough to build a 60 -m-high building - were used to entomb the dam- aged reactor. Workers have also built a concrete wall $15 \mathrm{~m}$ deep and approximately $6 \mathrm{~km}$ long around all four Chernobyl reactors to prevent seepage of radioactive material into local rivers. Decontamination teams cleaned some 60,000 buildings in nearly 500 villages in the area around Chernobyl. Remarkably, a small number of people have already returned to the villages around the reactor.

Velikhov told senators last week that there are important non-technical lessons to be learned from the accident. It is easy, he said, to become lulled into a false sense of confidence after years of accident-free operation. He criticized the United States

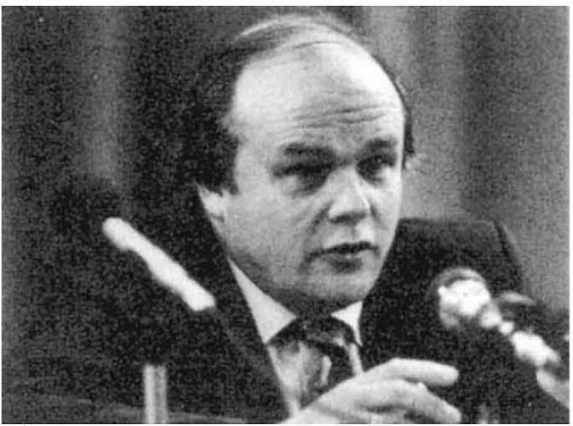

Velikhov faced a Senate committee in a twohour-long session.

for not making a stronger commitment to his own area of expertise, thermonuclear fusion research. But he conceded that Soviet dependence on nuclear power will grow for the rest of this decade. Plans now call for a fivefold increase in nuclear capacity by the year 2000 . Two of the four reactors at Chernobyl are now back in operation, one running at 50 per cent power, the other at 90 per cent.

On SDI, Velikhov said his government had made a major concession at Reykjavik by agreeing to permit continued laboratory research on SDI. Velikhov stressed that, by "laboratory testing", he did not mean only work carried out inside a building; field testing would be allowed, but only with weapons designed not to perform at full operational power.

Speaking to reporters after the hearing, Velikhov pointed out that if supposedly fail-safe systems in a nuclear power plant could fail, surely the chance of error in a programme as complex as SDI could not be ruled out. Velikhov believes it is vital to limit offensive weapons, as the next generation of weapons will be extremely complex and more prone to accidental use.

While in Washington, Velikhov also met Frank Press, president of the National Academy of Sciences, to discuss USSoviet scientific exchanges. He also talked with US organizers of an international meeting on arms control to be held in Moscow on 14-16 February. Joseph Palca

\section{Companies to pay for using others' ideas?}

\section{Rehovot}

COMPANIES that benefit financially from unpatented ideas used in manufacturing products should allocate 0.5 per cent of their earnings to fund the research of the scientists whose work they have exploited.

This firmly held view is that of Weizmann Institute Professor Meir Wilchek who has been a victim of patent law. The results of his research on peptide chemistry, affinity chromatography and the avidin-biotin system - like those of Nobel laureate César Milstein on monoclonal antibodies and of Professor Robert Gallo on interleukin 2 - were never properly patented.

Last week, together with Professor Pedro Cuatrecasas of Glaxo Inc. in the United States, Wilchek was awarded the $\$ 100,000$ Wolf Prize in Medicine for "the investigation and development of affinity chromatography and its application to biomedical sciences". Yet the fruits of Wilchek's work at the institute and at the US National Institutes of Health, which have helped commercial companies around the world earn tens of millions of dollars, have made only the slightest contribution to his personal finances and that of his research.

Wilchek, is satisfied to live on the very modest $\$ 1,200$ a month in take-home pay he receives from the Weizmann Institute, but he feels that it is unfair, even immoral, that commercial companies should be the sole beneficiaries of someone else's efforts, even if that is their legal right. He therefore proposes that companies manufacturing products directly based on unpatented scientific studies should voluntarily set aside 0.5 per cent of their net earnings for research grants to scientists from whom they have 'borrowed' ideas. This would be far less than the sum paid to scientists with valid patents, but it would be enough to encourage unconventional research.

Wilchek welcomes the grace period now incorporated in US law, which gives scientists up to a year after publication of papers to patent their new compounds and processes. But he thinks that is not long enough.

"After all", he points out, "three years passed between the initial papers (published in 1972) which prefaced the development of the avidin-biotin system, and my own realization of its great commercial significance. By then, of course, it was too late to obtain a patent. And only in the early 1980 s did the avidin-biotin system become big business."

Nechemia Meyers 